\title{
Characterization of the interaction between Actinin-Associated LIM Protein (ALP) and the rod domain of $\alpha$-actinin
} Tuula Klaavuniemi ${ }^{1}$, Nanna Alho
Heli Havukainen

Address: ${ }^{1}$ Biocenter Oulu and Department of Biochemistry, PO Box 3000, University of Oulu, 90014 Oulu, Finland, ${ }^{2}$ Department of Chemistry, PO Box 3000, University of Oulu, 90014 Oulu, Finland, ${ }^{3}$ Institute of Biotechnology, PO Box 56, University of Helsinki, 00014 Helsinki, Finland, ${ }^{4}$ Department of Pharmacology and Toxicology, PO Box 5000, University of Oulu, 90014 Oulu, Finland and ${ }^{5}$ Department of Biological and Environmental Science and Nanoscience Center, University of Jyväskylä, PO Box 35, 40014 Jyväskylä, Finland

Email: Tuula Klaavuniemi - tuula.klaavuniemi@oulu.fi; Nanna Alho - nanna.alho@oulu.fi; Pirta Hotulainen - philpela@mappi.helsinki.fi; Annina Kelloniemi - annina.kelloniemi@oulu.fi; Heli Havukainen - hhavukai@abo.fi; Perttu Permi - permi@cc.helsinki.fi; Sampo Mattila - sampo.mattila@oulu.fi; Jari Ylänne* - jylanne@bytl.jyu.fi

* Corresponding author

Published: 27 March 2009

BMC Cell Biology 2009, 10:22 doi:I0.II86/I47I-2I/2I-10-22
Received: 23 December 2008

Accepted: 27 March 2009

This article is available from: http://www.biomedcentral.com/I47I-2I $21 / / 0 / 22$

(c) 2009 Klaavuniemi et al; licensee BioMed Central Ltd.

This is an Open Access article distributed under the terms of the Creative Commons Attribution License (http://creativecommons.org/licenses/by/2.0), which permits unrestricted use, distribution, and reproduction in any medium, provided the original work is properly cited.

\begin{abstract}
Background: The PDZ-LIM proteins are a family of signalling adaptors that interact with the actin cross-linking protein, $\alpha$-actinin, via their PDZ domains or via internal regions between the PDZ and LIM domains. Three of the PDZ-LIM proteins have a conserved 26-residue ZM motif in the internal region, but the structure of the internal region is unknown.
\end{abstract}

Results: In this study, using circular dichroism and nuclear magnetic resonance (NMR), we showed that the ALP internal region (residues 107-273) was largely unfolded in solution, but was able to interact with the $\alpha$-actinin rod domain in vitro, and to co-localize with $\alpha$-actinin on stress fibres in vivo. NMR analysis revealed that the titration of ALP with the $\alpha$-actinin rod domain induces stabilization of ALP. A synthetic peptide (residues 175-196) that contained the $\mathrm{N}$-terminal half of the ZM motif was found to interact directly with the $\alpha$-actinin rod domain in surface plasmon resonance (SPR) measurements. Short deletions at or before the ZM motif abrogated the localization of ALP to actin stress fibres.

Conclusion: The internal region of ALP appeared to be largely unstructured but functional. The ZM motif defined part of the interaction surface between ALP and the $\alpha$-actinin rod domain.

\section{Background}

The muscle $\mathrm{Z}$ disc connects actin filaments from adjacent sarcomeres and is essential for force transmission and muscle integrity (for a recent review, see [1]). The main actin cross-linking protein in the $\mathrm{Z}$ disc is $\alpha$-actinin, an antiparallel dimer. Each of the $\alpha$-actinin monomers is composed of an N-terminal actin binding domain, a cen- tral rod region containing four spectrin repeats, and two pairs of EF-hands at the C-terminus (for review [2,3]).

One group of $\alpha$-actinin interacting $Z$ disc proteins, the PDZ-LIM or ALP/Enigma family [4], is characterized by Nterminal PDZ and C-terminal LIM domains (Fig 1A). Of these family members, actinin-associated LIM protein 


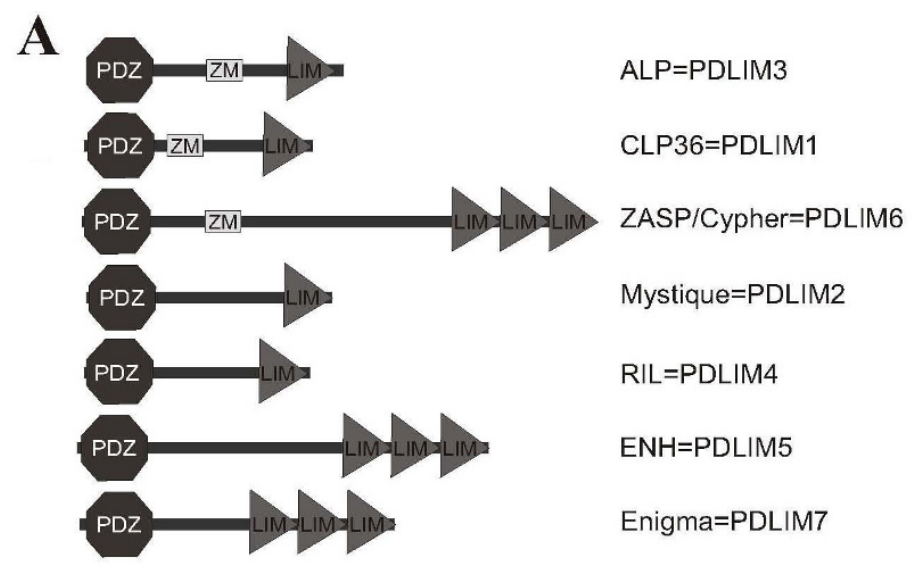

B

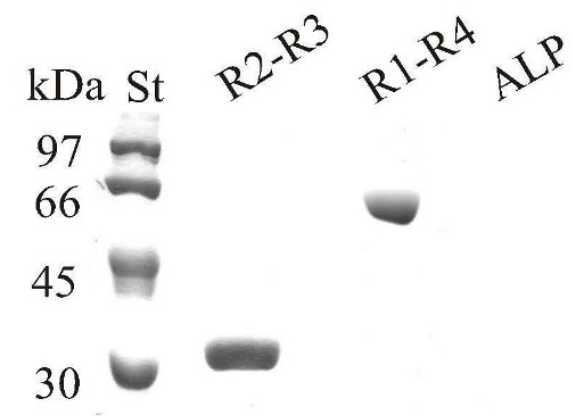

\section{1}

C

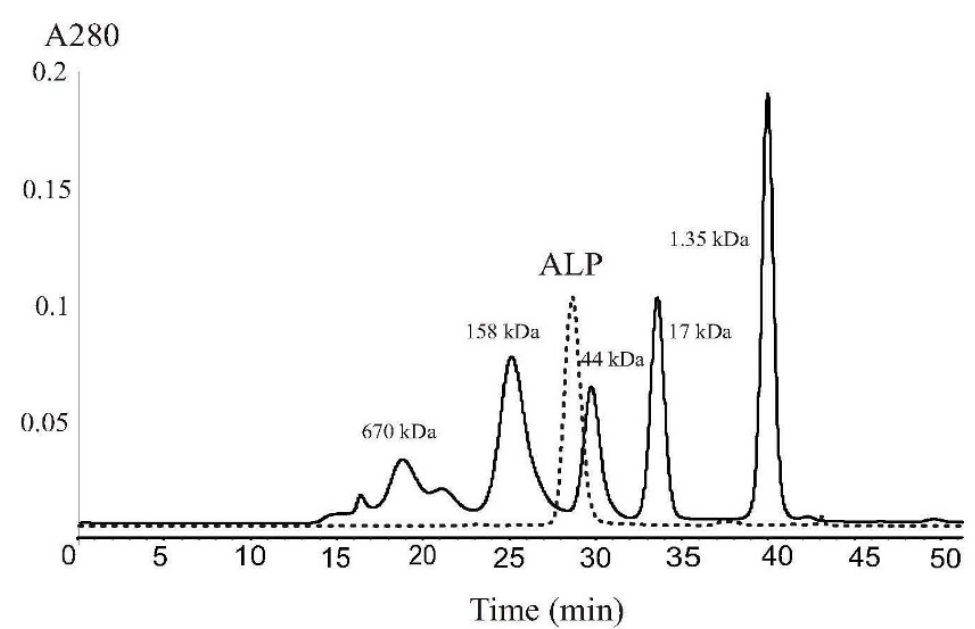

Figure I

Characterization of ALP 107-273 protein. A) Domain architecture of seven human PDZ_LIM proteins. B) SDS-PAGE of the proteins used in SPR measurements. R2-R3 denotes $\alpha$-actinin spectrin repeats 2-3, RI-R4 spectrin repeats I-4. ALP denotes the ALPI 07-273 fragment. Labelled ALPI07-273 used in NMR experiments had a similar purity to the non-labelled form. C) Size exclusion chromatography showed that ALPI07-273 eluted faster than expected based on its calculated monomer molecular weight (18 $265 \mathrm{Da})$. 
(ALP), the $\mathrm{Z}$ band alternatively spliced PDZ protein (ZASP/Cypher), Enigma and Enigma homology protein (ENH) are predominantly expressed in muscle [5-12]. In contrast, the C-terminal LIM protein (CLP36) is expressed both in muscle and non-muscle cells [13-17], while reversion-induced LIM protein (RIL) and Mystique are expressed in non-muscle tissues only [17-21]. Inactivation of ALP and ZASP/Cypher genes in mice leads to cardiomyopathy and muscle dystrophy phenotypes [22,23]. In Drosophila, the single ALP/ZASP/Enigma gene is required for $\mathrm{Z}$ disc organization and for muscle attachment [24].

The PDZ domains of many, if not all, of these proteins interact with the C-terminal peptide of $\alpha$-actinin $[6,23,25$ 27]. In addition, ALP, ZASP/Cypher and CLP36 interact with the $\alpha$-actinin rod domain [27-29] via sequences located between the PDZ and LIM domains, mapping close to a conserved 26 amino acid motif, the ZM motif, found in these three proteins $[27,29]$. Point mutations at or close to the ZM motif of ZASP/Cypher are found in cardiomyopathy patients $[30,31]$, but we have been unable to detect a direct effect of these mutations on interaction with $\alpha$-actinin [29].

The ZM motif is located in a sequence stretch of 200 or more residues between the PDZ and LIM domains of the ALP, ZASP/Cypher and CLP36, designated here as the internal region. Apart from the ZM motif and the recently found ALP-like motif [32], sequence diversity in the internal region is high, and in all family members there are areas 30-100 amino acid in length that are predicted to be unfolded by the program FoldIndex [33]. In this study, the aim was to structurally characterize the internal region of ALP and to further narrow its interaction site with the $\alpha$-actinin rod region. The ALP internal region was found to be essentially a random coil in solution and interaction with the $\alpha$-actinin rod could increase its stabilization. Furthermore, we found that a synthetic peptide covering part of the ZM motif interacted directly with the $\alpha$-actinin rod.

\section{Results \\ Expression and purification of ALP internal region fragments}

As the internal region of ALP is involved in localization of the protein and interaction with $\alpha$-actinin [27], it was of great interest to study the structure and function of this region in more detail. According to the SMART server [34], the PDZ domain of human ALP ends at amino acid residue 83 while the LIM domain begins at residue 294. In our previous studies [27], we used the fragment containing residues 112-284, but found that during purification this fragment often degraded. For this reason, we tried to find optimal protein fragments of the ALP internal region and we tested several different constructs around the area that had sequence features characteristic for folded domains when predicted with servers like Foldindex [33] (Fig 2) and DisEMBL [35]. We found that a 167 residue construct (ALP107-273) was optimally stable, and could be purified in high amounts and concentrated up to 30 $\mathrm{mg} / \mathrm{ml}$. SDS-PAGE analysis of this fragment revealed a single protein band of the expected molecular weight of 18265 Da (Fig 1B). The molecular weight of ALP107-273 was also verified by MALDI-TOF mass spectrometry. In gel filtration chromatography, the fragment eluted as a single peak immediately prior to the globular protein standard of $44000 \mathrm{Da}$ (Fig 1C), suggesting that it was either a very elongated monomer, dimer or trimer.

\section{Functional tests of ALPI07-273}

To test whether ALP107-273 was functional, we measured the interaction of the purified protein fragment with $\alpha$ actinin by surface plasmon resonance (SPR) and tested the localization of a yellow fluorescent protein (YFP) fusion protein construct in living cells. The SPR measurements were made either by immobilizing ALP107-273 on the chip, using the $\alpha$-actinin rod fragments as a soluble analyte, or the other way around. A clear interaction was observed in both experimental setups (Figs 3A and 3B) and the apparent dissociation equilibrium constants $\left(\mathrm{K}_{\mathrm{d}}\right)$ were in the low micromolar range. When an $\alpha$-actinin rod fragment consisting of four spectrin repeats (R1-R4) was immobilized and ALP107-273 used as the analyte, the $\mathrm{K}_{\mathrm{d}}$ was $2.7 \times 10^{-7} \mathrm{M}$. With immobilized ALP107-273 and soluble R1-R4, the $\mathrm{K}_{\mathrm{d}}$ was $4.5 \times 10^{-6} \mathrm{M}$. These values are in the same range as our previous measurements that used longer ALP fragments [27]. ALP107-273 interacted with a shorter piece of the $\alpha$-actinin rod region that contained two spectrin repeats (R2-R3) with an apparently higher affinity $\left(\mathrm{Kd}=6.8 \times 10^{-9}\right)$ than it did with R1-R4 (Fig 3C).

The YFP-fusion construct of ALP107-273 was expressed in U2OS cells together with the $\alpha$-actinin cyan fluorescent protein (CFP). In these cells, $\alpha$-actinin localizes to the leading lamellipodia, to focal adhesions and to actin stress fibres. In contractile stress fibres, $\alpha$-actinin exhibits a punctate pattern (Fig 4A, D and red in 4C, F). ALP107273 co-localized with $\alpha$-actinin in the stress fibres, but no co-localization was seen in either the cell edge or the focal adhesions (Fig 4B, E and green in 4C, F).

Taken together, the SRP interaction measurements and live cell experiments using YFP fusion protein indicated that ALP107-273 interaction with $\alpha$-actinin was similar to the full length ALP [27].

\section{Structural characterization of ALPI07-273}

To study the structure of ALP107-273 we utilized circular dichroism (CD) and nuclear magnetic resonance (NMR) spectroscopy. The CD spectrum suggested that ALP107273 is mostly unfolded (Fig 5A). No features characteristic 
A

1 MPQTVILPGP APWGFRLSGG IDFNQPLVIT RITPGSKAAA ANLCPGDVIL 50

51 AIDGFGTESM THADAQDRIK AAAHQLCLKI DRGETHLWSP QVSEDGKAHP 100

101 FKINLESEPO DGNYFEHKHN IRPKPFVIPG RSSGCSTPSG IDCGSGRSTP 150

151 SSVSTVSTIC PGDLKVAAKL APNIPLEMEL PGVKIVHAOF NTPMOLYSDD 200 201 NIMETLOGOV STALGETPLM NEPTASVPPE SDVYRMLHDN RNEPTOPROS 250

251 GSFRVLQGMV DDGSDDRPAG TRSVRAPVTK VHGGSGGAQR MPLCDKCGSG 300

301 IVGAVVKARD KYRHPECFVC ADCNLNLKQK GYFEIEGELY CETHARARTK 350

351 PPEGYDTVTL YPKA $\quad 364$

$\mathrm{B}$

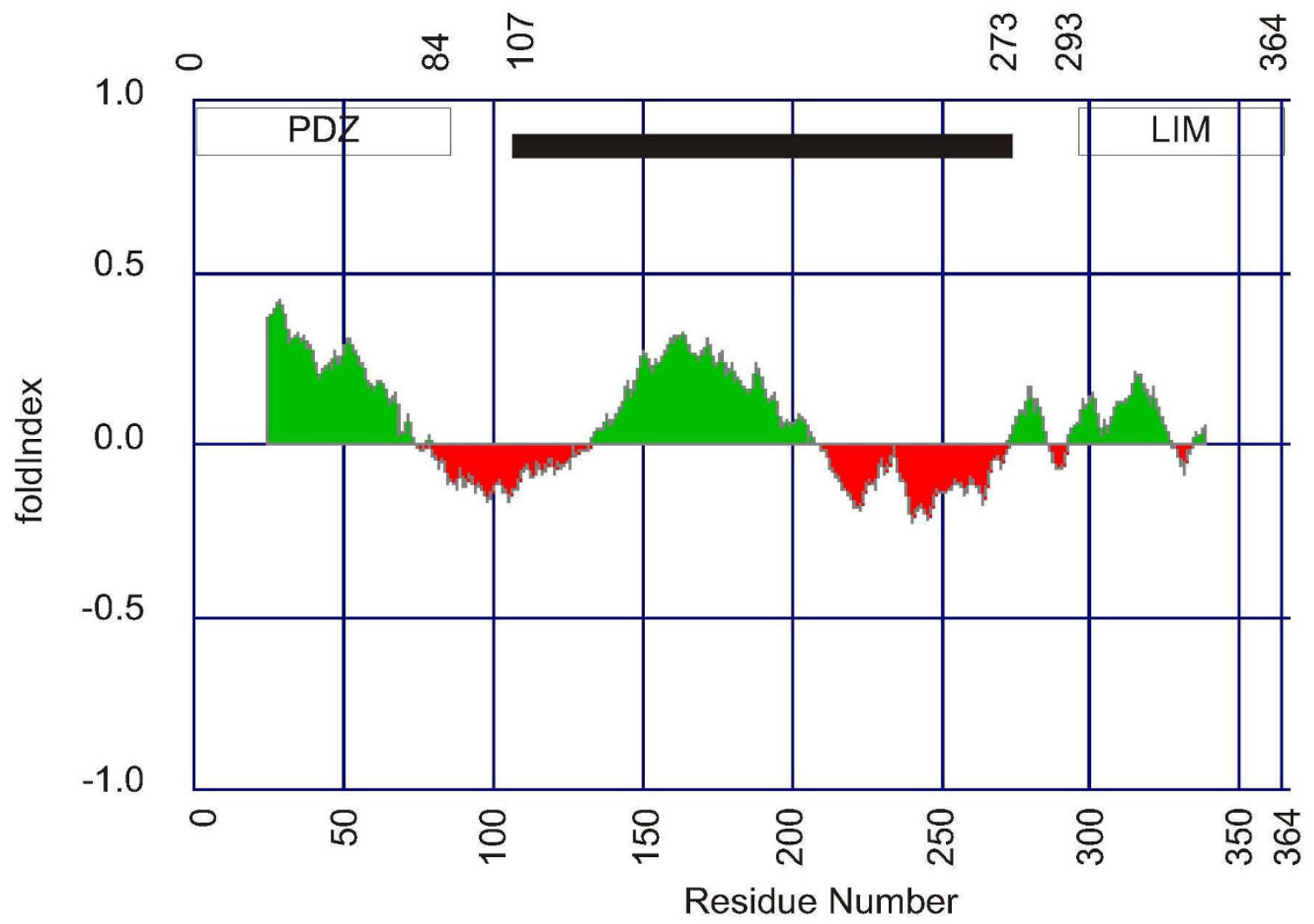

folded

unfolded

Figure 2

Amino acid sequence analysis. A) The full sequence of human ALP is shown. The PDZ domain is shown in red, the ZM motif in blue and the LIM domain in yellow. The 107-273 fragment used in this study is underlined. B) Analysis of ALP with the Foldindex server http://bioportal.weizmann.ac.il/fldbin/findex. Predicted folded areas are indicated in green and unfolded areas in red. The boxes above the graph indicate the PDZ and LIM domains as well as the 107-273 fragment. 


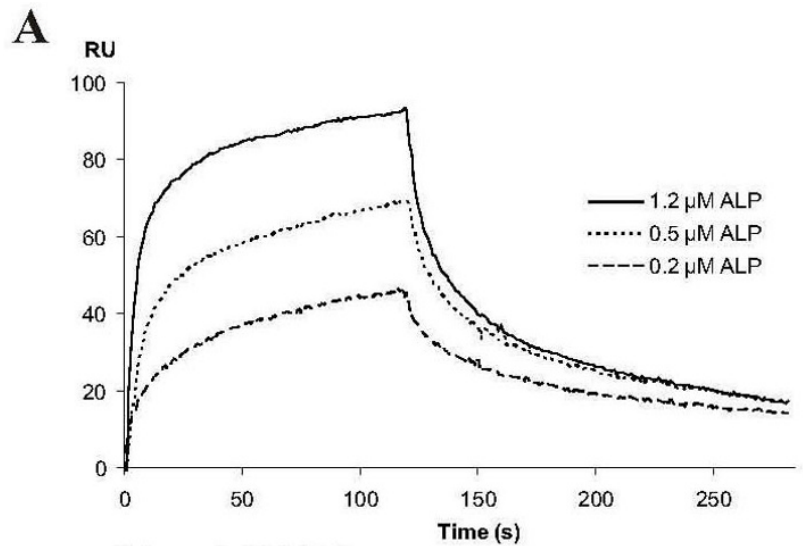

Ligand: R1-R4

\section{B}

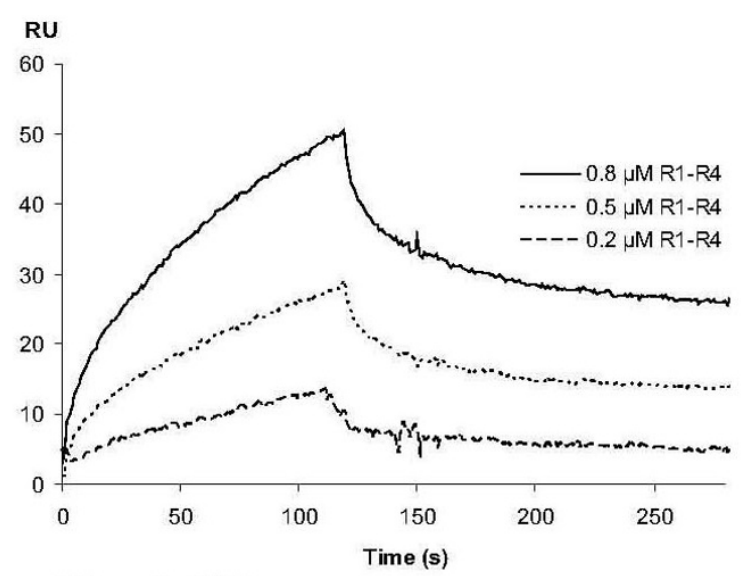

Ligand: ALP

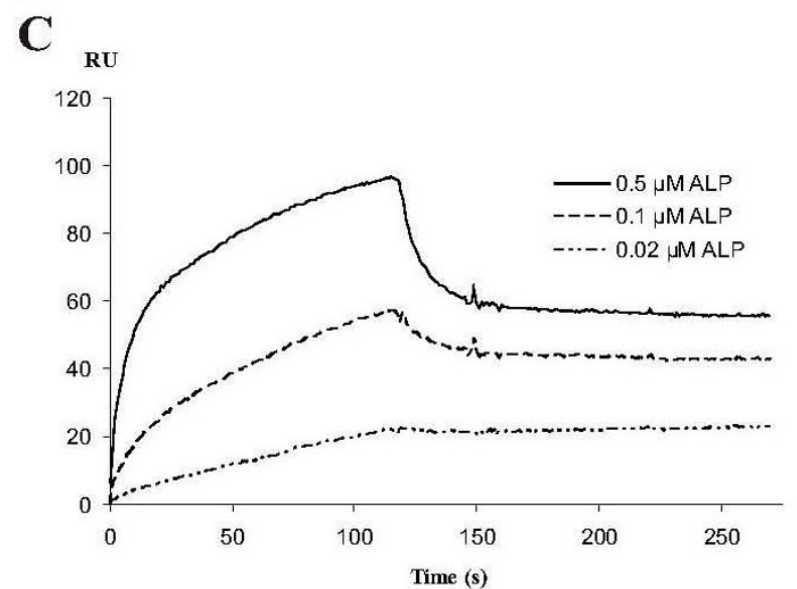

Ligand:R2-R3

\section{Figure 3}

SPR measurements of ALP 107-273/ $\alpha$-actinin interaction. A) ALPI07-273 as the soluble analyte with immobilized $\alpha$ actinin spectrin repeats I-4 (RI-R4). B) RI-R4 interaction with immobilized ALPI07-273. C) ALPI07-273 interaction with immobilized $\alpha$-actinin spectrin repeats $2-3$ (R2-R3). 

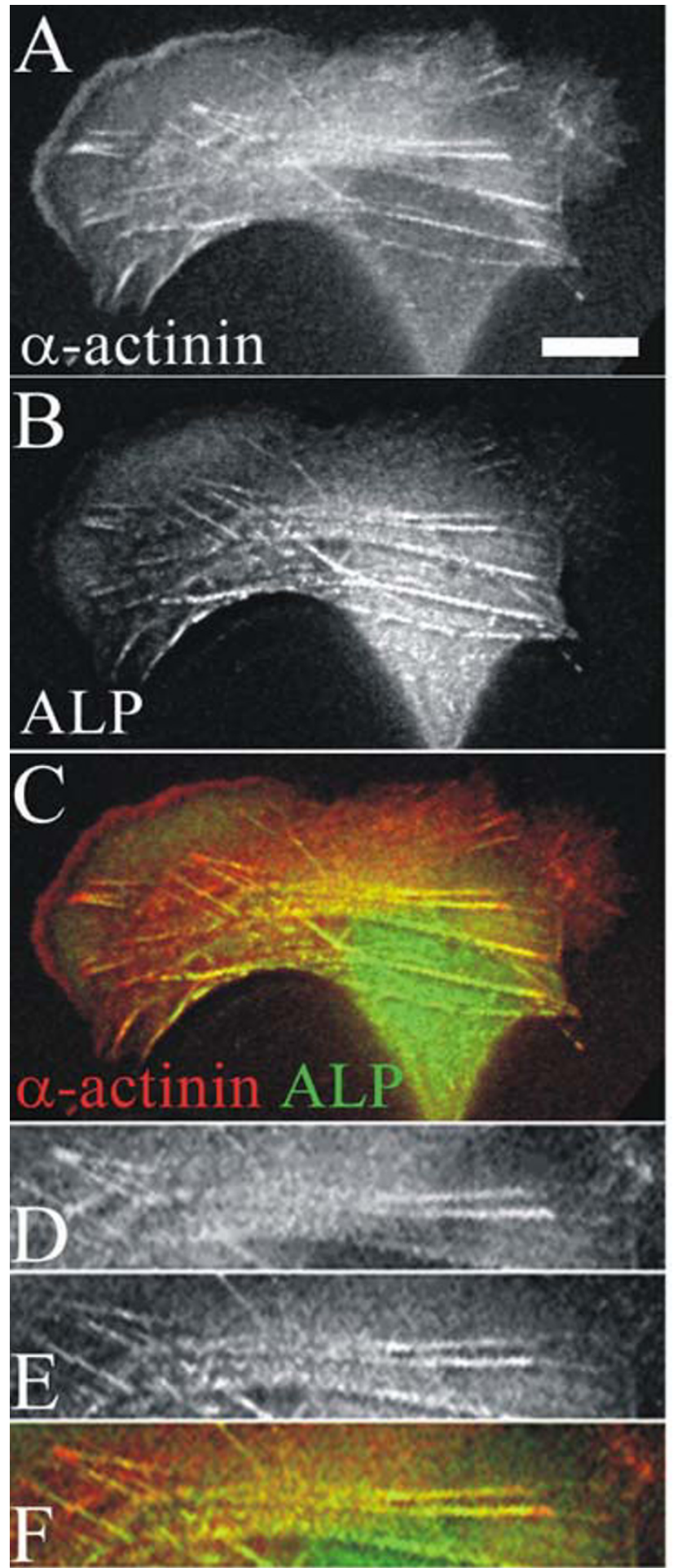

\section{Figure 4}

Localization of ALP I 07-273 in living cells. Fluorescence micrograph of a U2OS cell expressing $\alpha$-actinin-CFP ( $A$ and red in C) and YFP-ALPI07-273 (B and green in C). A higher magnification view of a region containing stress fibres is displayed in the bottom three panels (D, E, F). Bar $10 \mu \mathrm{m}$. of either $\alpha$-helical or $\beta$-sheet structures were seen. In comparison, the CD spectrum of ALP1-273 showed a slight increase in $\beta$-strand content that might be attributed to the PDZ domain (Fig 5A).

The first ${ }^{15} \mathrm{~N}-\mathrm{HSQC}$ spectrum measured in normal buffer conditions from uniformly ${ }^{15} \mathrm{~N}$-labeled ALP107-273 was in line with the CD measurements as it showed the collapsed spectrum characteristic of an unfolded protein (Fig $5 \mathrm{~B}$, green). However, we were able to partially stabilize the structure by adding $40 \mathrm{mM}$ Aspartic acid $\mathrm{pH} 4.0$ (Fig. 5B, red) $[36,37]$. Under these conditions, iHNCA, HNCA, HNCACO, HNCO, HNCOCA, HNCACB and $\mathrm{CBCA}(\mathrm{CO}) \mathrm{NH}$ spectra were acquired and used for backbone assignment [38]. The ALP107-273 fragment contained 167 residues, of which 16 were prolines. All together, 147 of the 151 non-proline residues could be assigned. When the ${ }^{13} \mathrm{C}$ chemical shift values of all assigned $C \alpha$ and $C \beta$ atoms were compared to the average value of the corresponding residues in random coil conformation [39], no clear indications of either $\alpha$ helix or $\beta$ sheet secondary structures were observed (Fig 6). Thus, NMR analysis indicated that ALP107-273 was mostly unstructured with no secondary structure.

The interaction with the $\alpha$-actinin rod region could have induced some structural changes in ALP107-273. Assessing this by titration was complicated because the complex between ALP107-273 and the large $\alpha$-actinin rod dimer of $114 \mathrm{kDa}$ was undetectable by NMR. To be able to measure the spectrum of an unbound ALP107-273 that is in dynamic equilibrium between $\alpha$-actinin bound and unbound states, we used a rather low concentration of ALP107-273 and observed increasing levels of ALP107$273{ }^{15} \mathrm{~N}$-HSQC peaks upon addition of $\alpha$-actinin (Fig $5 \mathrm{C})$. Most of the peaks $(110$, or $75 \%)$ could be correlated with those assigned in the presence of $40 \mathrm{mM}$ Aspartic acid. Only a minor fraction of the peaks were induced by ALP dilution alone (Fig 5D). The NMR titration studies suggested that structure of ALP107-273 was partially stabilized by the interaction with the $\alpha$-actinin rod region.

\section{Mapping of the interaction site with synthetic peptides and deletions}

As NMR studies suggested that ALP107-273 could exist in an elongated, unfolded conformation, even when interacting with $\alpha$-actinin, we chose to map the interaction site using overlapping synthetic peptides (20-22 residues long). We focused our efforts on the minimum interaction area mapped by truncation mutagenesis, namely ALP residues 151-232, which included the ZM motif [27]. The sequences of these peptides are shown in figure 7A. Only peptide 3 (PLEMELPGVKIVHAQFNTPMQL, corresponding to residues 175-196) bound to the immobilized $\alpha$ actinin rod domain (composed of spectrin repeats R1-R4) 
A

Mean molar ellipticity

$\left(10^{3} \mathrm{deg} \mathrm{cm}^{2} \mathrm{dmol}^{-1}\right)$

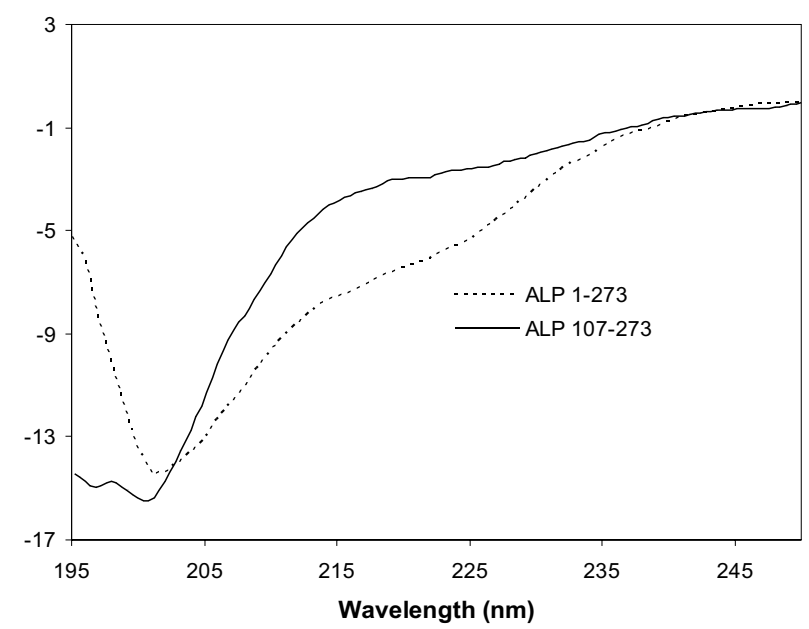

C

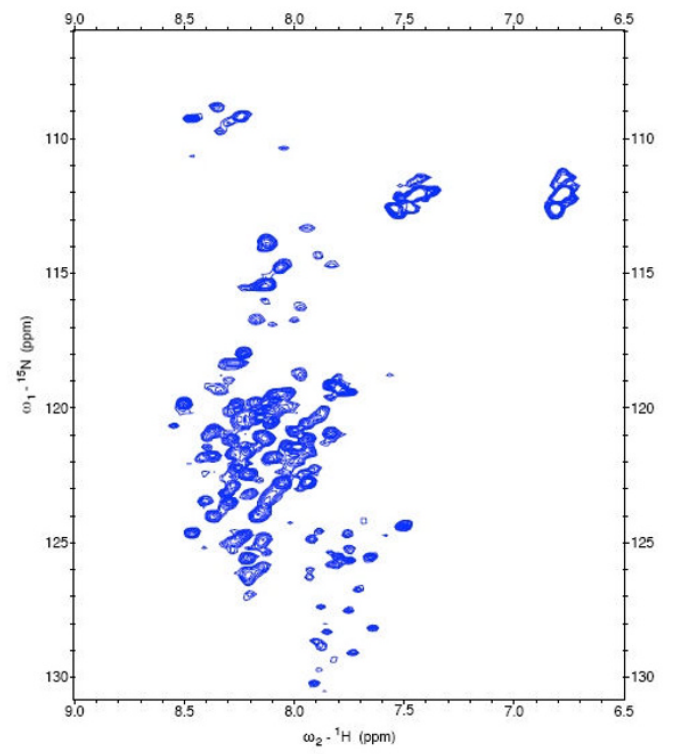

B

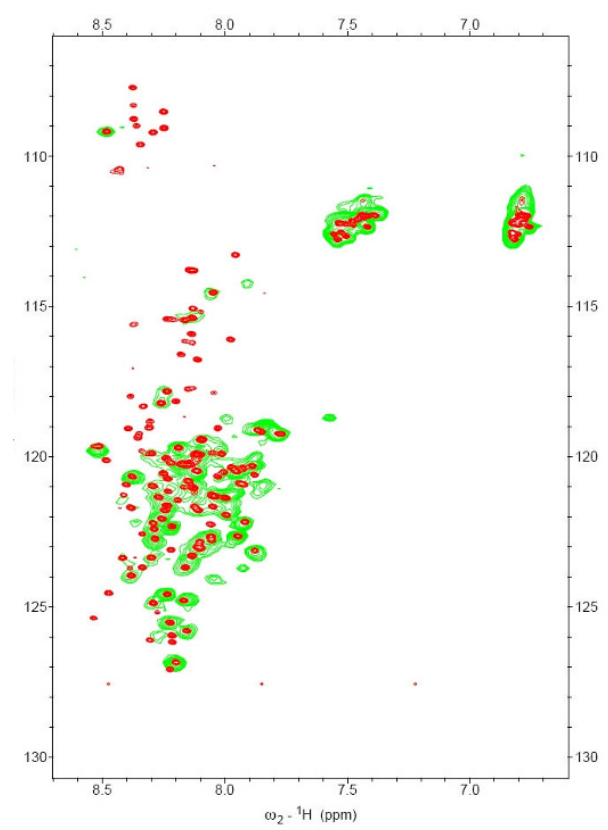

D

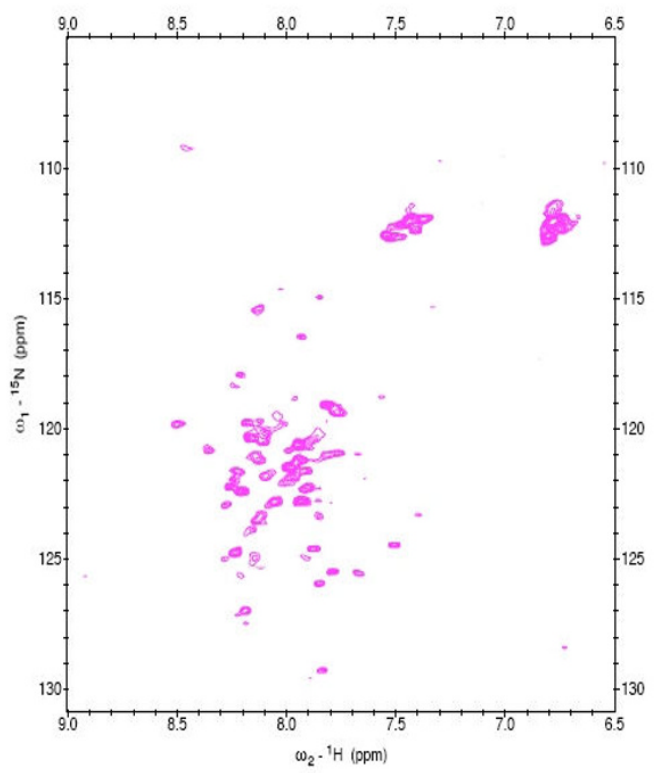

\section{Figure 5}

Structural analysis of ALP 1 07-273. A) The CD spectrum of ALPI 07-273 is consistent with a random coil conformation, whereas the PDZ domain containing ALPI-273 fragment has some $\beta$-strand features. B) Overlaid ${ }^{15} \mathrm{~N}$ HSQC NMR spectra of $1.6 \mathrm{mM}$ ALPI07-273 in the purification buffer (green) and after addition of $40 \mathrm{mM}$ Asp (red). C) ${ }^{15} \mathrm{~N}-\mathrm{HSQC}$ spectrum of $84 \mu \mathrm{M}$ ALPI07-273 in the presence of $218 \mu$ M unlabelled RI-R4. D) Identical spectra as in C taken from $80 \mu M \mu M$ ALPI07-273 alone. The low intensity signals in the lower right part of the spectra in $C$ and $D$ are observed for ALP concentrations under $100 \mu \mathrm{M}$, and apparently represent another conformation of ALP. Owing to low sample concentration, no attempt was made to assign these signals. 
A

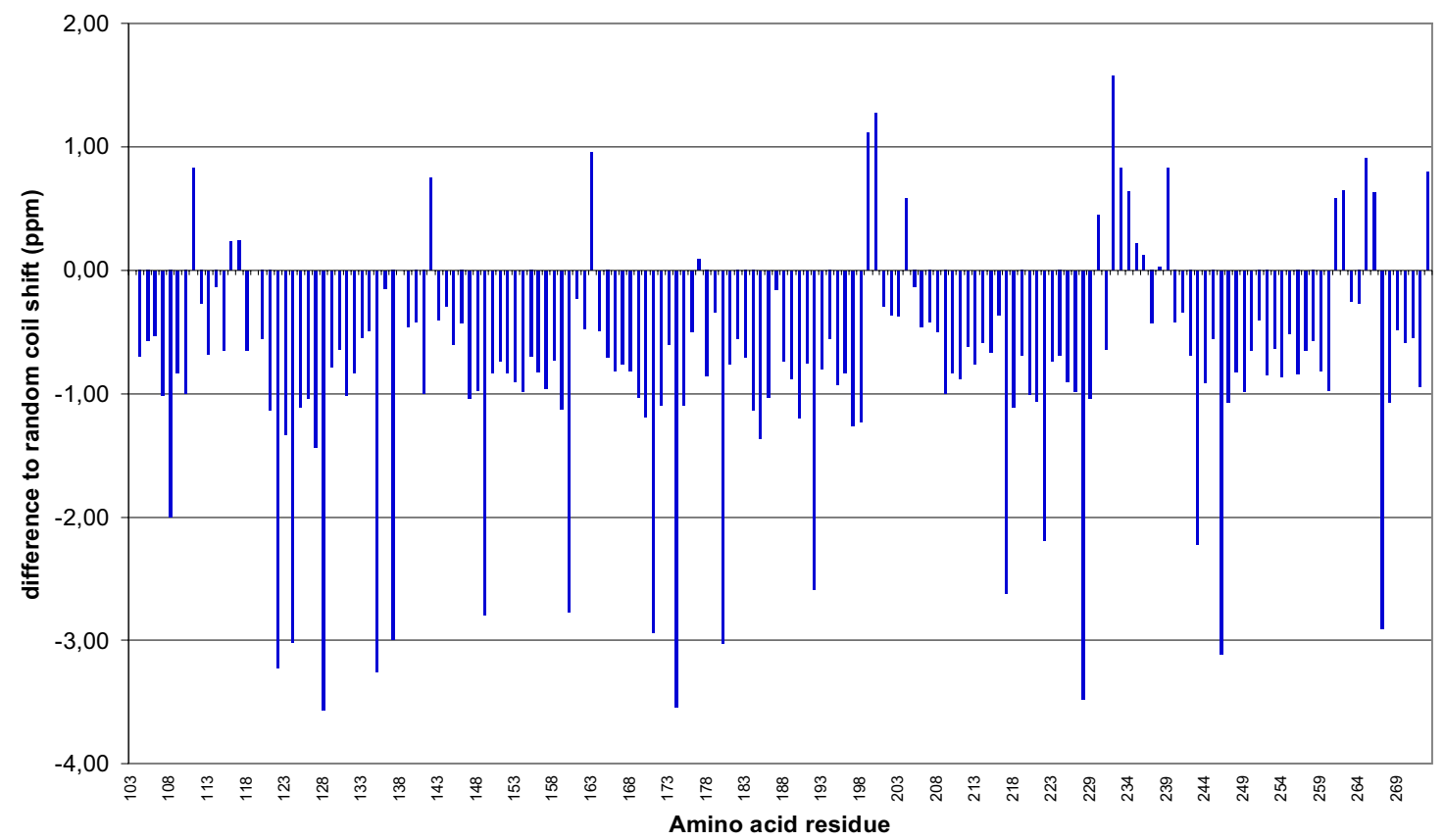

B

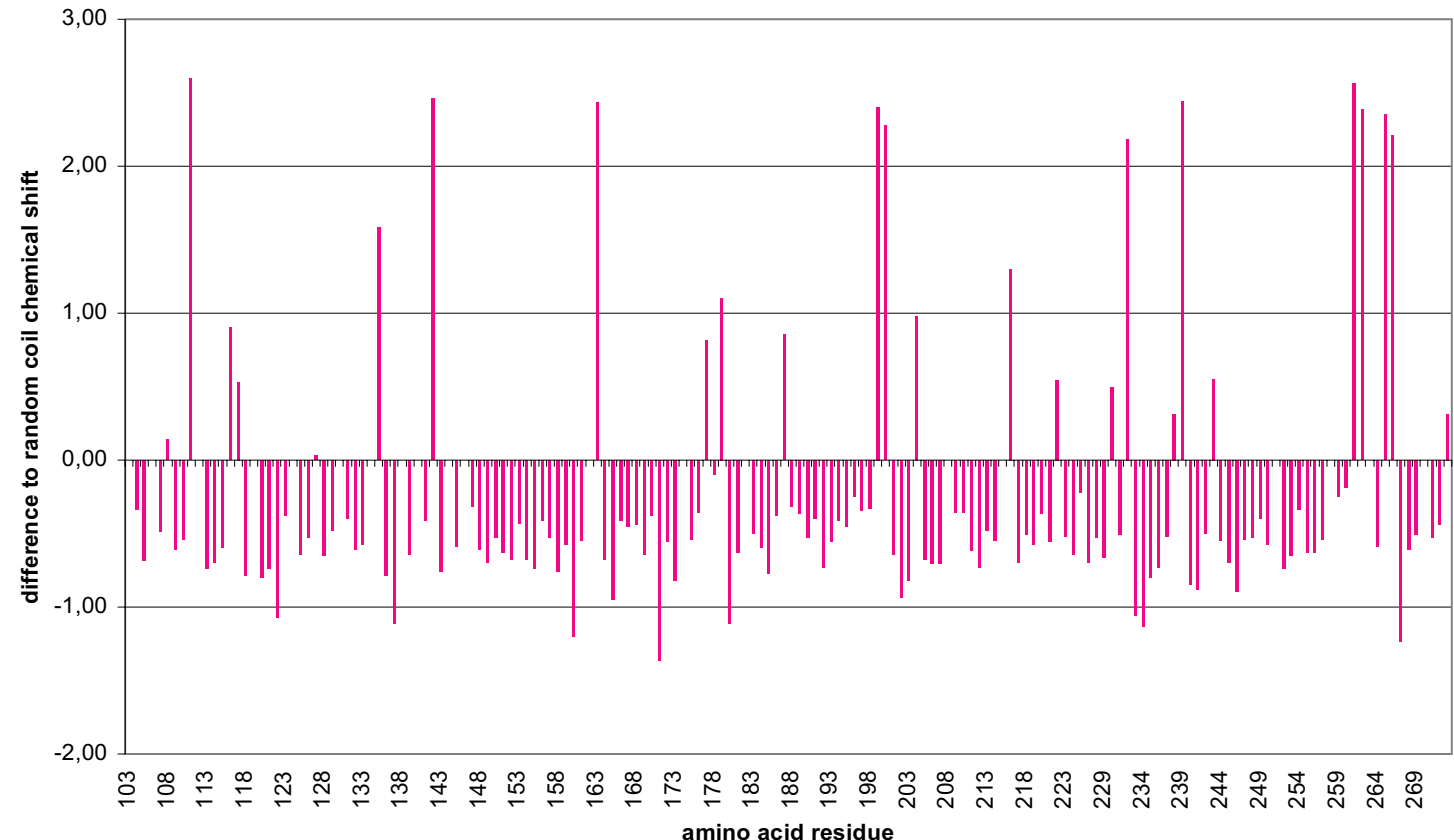

Figure 6

Comparison of ALP I 07-273 NMR chemical shifts with those observed in random coil conformations. A) Difference of ${ }^{13} \mathrm{C} \mathrm{C} \alpha$ chemical shifts with random coil as a function of amino acid residue number. The random coil values were taken from the Biological Magnetic Resonance Data Bank http://www.bmrb.wisc.edu. The average difference for ${ }^{13} \mathrm{C} \mathrm{C} \alpha \mathrm{chem}$ ical shifts in an $\alpha$-helix is +3 and in a $\beta$ sheet is $-I .5$ [39]. B) The difference in ${ }^{13} \mathrm{C} \mathrm{C} \beta$ chemical shift to random coil conformation. The average reference value is $-I$ in an $\alpha$ helix and +3 in a $\beta$ sheet [39]. Based on this analysis ALPI07-273 does not appear to contain sequential residues with typical $\alpha$ helix or $\beta$ sheet conformations. 
A

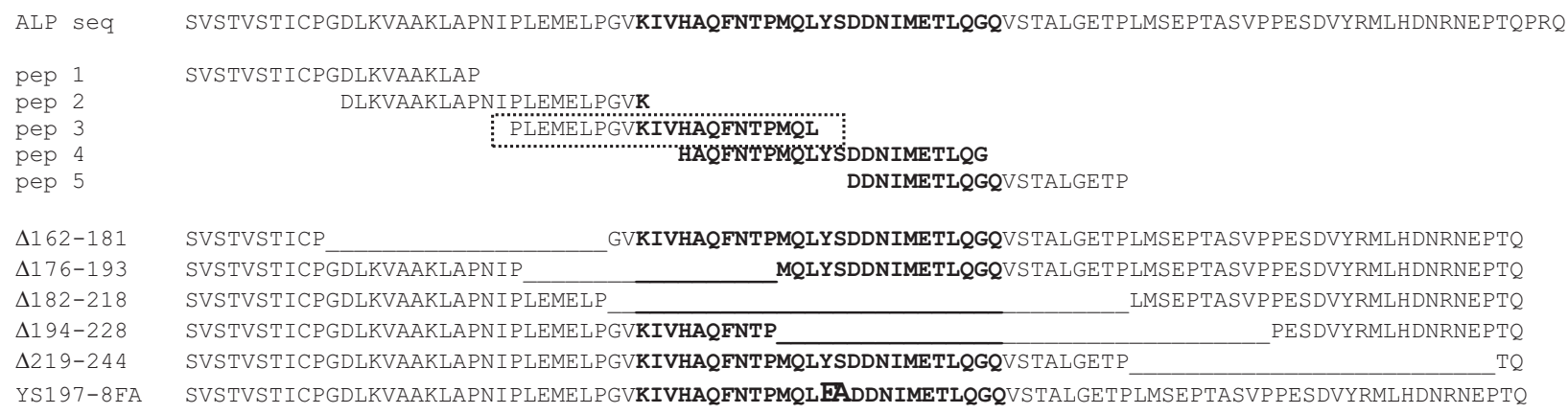

B

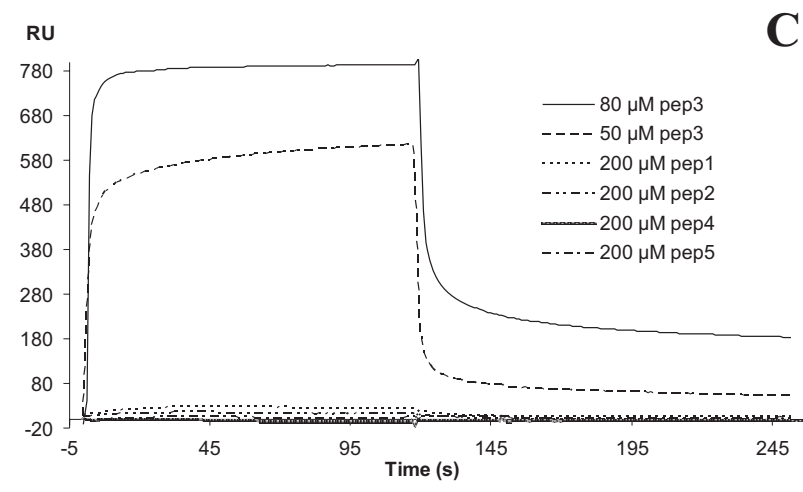

D
RU

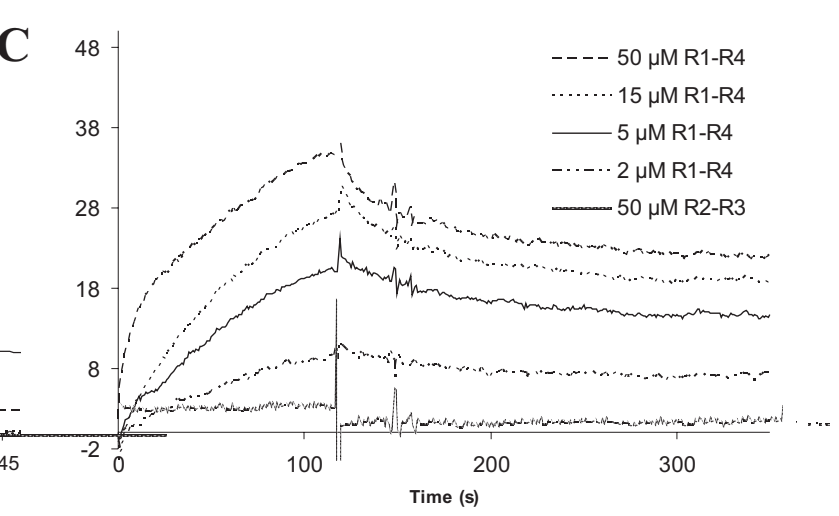

Ligand: ALP peptide 3

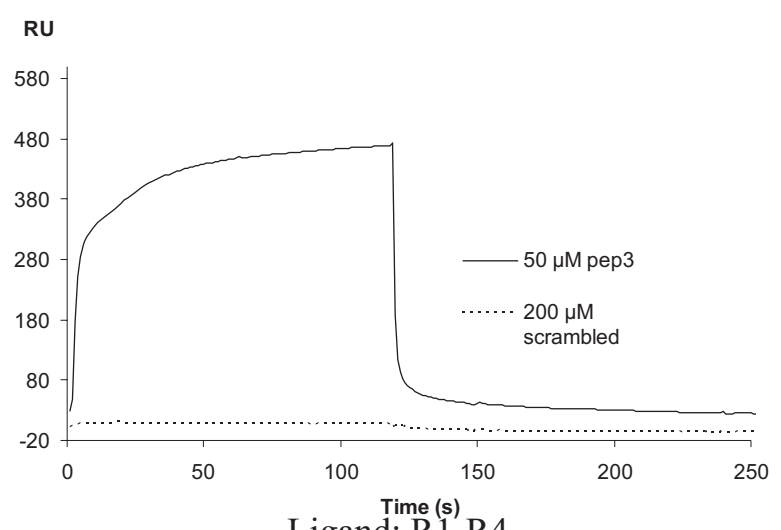

Ligand: Rime (s)

\section{Figure 7}

SPR analysis of peptide interactions. A) The ALP sequence between residues 152 and 246 with the ZM consensus motif marked in bold. Sequences of five overlapping peptides of ALP internal region are shown next, followed by the five deletion mutants and one point mutant. B) SPR sensograms showing that ALP peptide 3 interacts with the rod domain, whereas peptides I, 2, 4 and 5 do not. RI-R4 was used as a ligand. C) RI-R4 interaction with ALP peptide 3 (used as a ligand) is concentration-dependent, but R2-R3 does not interact with peptide 3. D) Comparison between the binding of peptide 3 and its scrambled version containing the same amino acids in random order. 
in the SPR experiments. A clear interaction was seen with $50 \mu \mathrm{M}$ and $80 \mu \mathrm{M}$ peptide concentrations, whereas the other four peptides failed to interact even at $200 \mu \mathrm{M}$ concentrations (Fig 7B). To verify the interaction of peptide 3 with the rod, peptide 3 was immobilized and the rod was used as the soluble analyte (Fig 7C). The rod interacted with the peptide with apparent $\mathrm{K}_{\mathrm{d}}$ of $3.0 \times 10^{-6} \mathrm{M}$. However, in contrast to the ALP107-273 fragment, peptide 3 did not interact with R2-R3 (Fig 7C). A scrambled version of peptide 3 (MNKPEQALLVQIHPLVTEPFMG) did not interact with the rod domain, verifying the sequence specificity of the interaction with the rod (Fig 7D). Thus, an area of residues 175-196 containing the N-terminal half of the ZM motif of ALP appeared to interact directly with the $\alpha$-actinin rod domain, but not with its two central spectrin repeats, R2-R3.

The peptide binding studies suggested that sequences before and at the ZM motif of ALP are sufficient for interaction with $\alpha$-actinin. To further test if this region was really necessary for the interaction, we constructed five overlapping deletions in ALP107-273 between residues 162 and 244. The deletions were 18-37 amino acids long and each was designed to include a stretch between two proline residues (Fig 7A). Four deletions that overlapped with peptide 3 totally abrogated the ability of ALP107-273 to localize at stress fibres (Fig 8), whereas a deletion after the $\mathrm{ZM}$ motif did not affect the localization. As the $\mathrm{ZM}$ motif contains conserved tyrosine and serine residues that

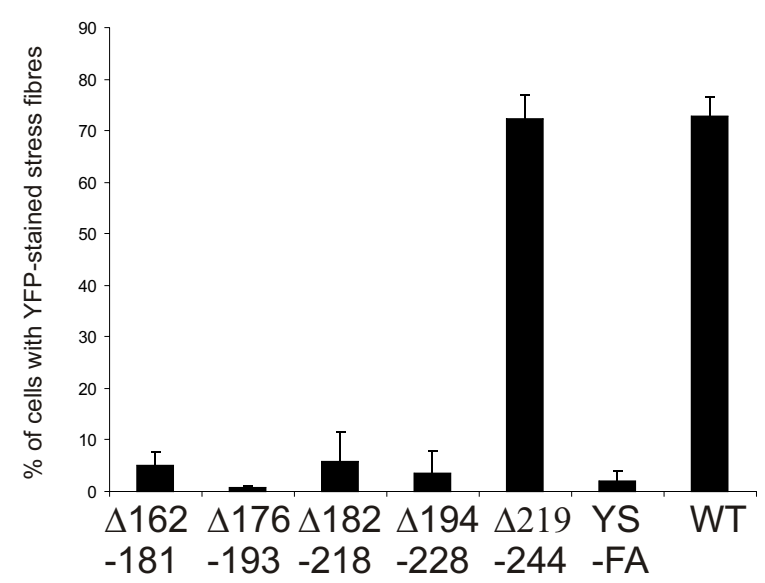

Figure 8

Deletion mutations at the $Z M$ region disrupt ALP I 07-273 localization. The percentages of cells with YFP localization at stress fibres. YFP was fused to ALPI07273 without any modifications (WT) or with deletions or mutations (deletions and mutations shown in graph). Note that four deletion mutants and the YSI97-198FA point mutation (YS-FA) abrogated localization. In cells expressing YFP alone, $<$ I\% were scored positive. might be phosphorylated, we also made point mutations where these residues were changed to phenylalanine and alanine, respectively. This mutant also failed to localize to stress fibres (Fig 6). Taken together, the peptide binding studies and the mutant studies suggested that the ZM motif is sufficient and necessary for ALP interaction with $\alpha$-actinin in the stress fibres.

\section{Discussion}

$\alpha$-Actinin interacting PDZ-LIM proteins are important for sarcomeric integrity as well as being involved in hypertrophic stretch activated signalling pathways in the muscle $\mathrm{Z}$ disc (for reviews, see [40-43] via their interactions with protein kinase $\mathrm{C}$ isoforms and calsarcins $[9,22,23,30,31,44,45]$. Although the PDZ and LIM domains are well-known protein folds, the functional and structural properties of the internal regions in this family of proteins are still poorly characterized.

In previous studies, we showed that ALP, CLP36 and ZASP/Cypher, which all have a ZM motif in the internal region, interacted with the $\alpha$-actinin rod and that the $Z M$ motif (ALP residues 184-209) might be important for this interaction $[27,29]$. In the current paper, we have been able to map the interaction site in more detail. We showed that a synthetic peptide spanning ALP residues 175-196 was able to interact directly with the $\alpha$-actinin rod. Two other peptides spanning parts of the ZM motif did not interact and neither did two peptides before the ZM motif. On the other hand, several deletion mutants before or at the ZM motif abrogated the localization of YFP-ALP fragments to $\alpha$-actinin containing structures. Notably, a deletion after the ZM motif had no effect. A mutation at the conserved Tyr-Ser sequence in the ZM motif (residues 197-198) also abrogated localization of ALP in cells. Further studies are required to test whether this effect is dependent on phosphorylation, and whether phosphorylation could explain the lack of ALP in focal adhesions where $\alpha$-actinin is located.

Thus, our peptide binding studies and deletion mutations suggest that the ZM motif is directly involved in the interaction with the $\alpha$-actinin rod. However, these results do not rule out the involvement of other areas of the ALP internal region in the interaction. On the contrary, the involvement of other areas was suggested by the finding that while peptide 3 interacted strongly with the $\alpha$-actinin rod fragment composed of four spectrin repeats (R1-R4), it did not interact with the two central spectrin repeats (R2-R3) of $\alpha$-actinin. The ALP107-273 fragment, on the other hand, interacted with both R1-R4 and R2-R3 fragments. These data are compatible with a hypothesis that the ALP internal region may have an extended interaction surface on $\alpha$-actinin and that the interaction surface may cover a large area of the $\alpha$-actinin rod domain. 
Structural analysis showed that the ALP internal region is largely unstructured and that interaction with $\alpha$-actinin partially stabilizes its conformation, but does not induce any detectable secondary structure elements. We showed previously that two ALP molecules can interact with the dimeric $\alpha$-actinin rod domain [27]. Combining this information with our current structural and hydrodynamic analyses suggests that the ALP internal region is an elongated, flexible monomer in solution, although we cannot exclude the formation of dimer. Notably, despite a lack of ordered structure, this fragment is rather stable and it can be expressed, purified and concentrated to a high degree. Based on sequence analysis by programs such as FoldIndex [33] or DisEMBL [35], the ALP internal region cannot be classified as being intrinsically unfolded (Fig 2). Analysis of the corresponding regions of other PDZ-LIM family members with the same programs yielded quite similar results (data not shown).

\section{Conclusion}

Our current data are compatible with the hypothesis that the ALP internal region exists in an open, flexible conformation and forms a long interaction surface with the $\alpha$ actinin rod region. We have also shown that sequences both before and at the conserved ZM motif are required for interaction with $\alpha$-actinin and that a short peptide from this area can interact directly.

\section{Methods}

\section{Constructs used}

Internal fragments of human ALP (AF039018) and chicken ALP ( $\underline{\text { AJ249218) }}$ ) were cloned into a modified pET24d vector (Novagen, Merck Biosciences, Schwalbach, Germany) as described earlier [27] using BsmBI (NcoI)NotI cloning sites. Rod fragments containing spectrin repeats 1-4 (residues 274-746) or repeats 2 and 3 (residues 371-637) of human $\alpha$-actinin 2 have been described previously [46,47]. A YFP-fusion of ALP107-273 was generated in a PEYFP-C1 vector (Clontech, BD Biosciences) at an EcoRI-BamHI restriction site. The deletion constructs of pEYFP-ALP107-273 were generated by PCR. The $\alpha$ Actinin-CFP construct is described elsewhere [48]. All constructs were verified by DNA sequencing.

\section{Protein expression and purification}

ALP internal fragments and an $\alpha$-actinin rod containing the spectrin repeats 1-4 (R1-R4) and a fragment containing spectrin repeats 2 and 3 (R2-R3) were expressed at $+37^{\circ} \mathrm{C}$ for 3-4 h in Escherichia coli BL21(DE3) strain as previously described [27]. Briefly, proteins were purified using nickel nitrilotriacetic acid-agarose (Qiagen) as a first step. The His-tag was removed by tobacco etch virus protease (Invitrogen). For further purification, size exclusion chromatography (Superdex 75 16/60 and 26/60 columns, Amersham Biosciences) for ALP, and ion exchange (ProteinPakQ 8HR columns, Waters) for $\alpha$-actinin fragments were used. The molecular weight standards for the gel filtration were obtained from Bio-Rad Laboratories. For NMR analysis, ${ }^{15} \mathrm{~N}$-labelled ALP107-273 and ${ }^{15} \mathrm{~N}^{13} \mathrm{C}$ labelled ALP107-273 were produced in general M9-media with supplements [49]. Expression was induced with 1 $\mathrm{mM}$ isopropyl-1-thio- $\beta$-D-galactopyranoside (IPTG) at $+37^{\circ} \mathrm{C}$ for 8 hrs in E. coli BL21(DE3) strain. Low molecular weight markers used in SDS-polyacrylamide electrophoresis were obtained from Amersham Biosciences. Five ALP peptides were purchased from EZBiolab Inc. (Westfield, IN, USA).

\section{Circular dichroism}

A JASCO J-715 spectrometer (JASCO Corporation, Hachioji City, Tokyo, Japan) was used for circular dichroism measurements. Purified ALP proteins at a concentration of approximately $30 \mathrm{mg} / \mathrm{ml}$ were diluted to $0.15 \mathrm{mg} /$ $\mathrm{ml}$ with $20 \mathrm{mM}$ Tris, $\mathrm{pH} 8$ buffer. The far-UV spectrum $(195-250 \mathrm{~nm})$ was measured at $20^{\circ} \mathrm{C}$ and the background effect of buffer was subtracted. The instrument settings were as follows: response $1 \mathrm{sec}$, scan speed $50 \mathrm{~nm} /$ min, cell length $0.1 \mathrm{~mm}$, number of scans 16 .

\section{Localization studies of ALP mutants}

The pEYFP ALP107-273 and mutants were transfected into $\mathrm{CHO}$ cells as described previously [27]. Following $24 \mathrm{hrs}$ transfection, the cells were seeded for 4 hrs on coverslips coated with $10 \mu \mathrm{g} / \mathrm{ml}$ human plasma fibronectin (Sigma) and fixed with $4 \%$ paraformaldehyde in $140 \mathrm{mM} \mathrm{NaCl}, 10$ $\mathrm{mM}$ Na-Phosphate $\mathrm{pH}$ 7.4. The coverslips were coded and the number of cells with YFP localization at stress fibres was counted by two observers who were blinded to the identity of the samples. At least 100 cells were scored from each coverslip, four coverslips were used per transfection, and the experiment was repeated at least three times.

\section{Live cell microscopy}

Human osteosarcoma (U2OS) cells were maintained in Dulbecco's modified Eagle's medium (DMEM) supplemented with $10 \%$ fetal bovine serum (Hyclone), $2 \mathrm{mM} \mathrm{L-}$ glutamine, penicillin and streptomycin (Sigma-Aldrich). Transfected cells were re-plated on fibronectin $(10 \mu \mathrm{g} / \mathrm{ml})$ coated glass bottom dishes (MatTek). General growth medium was used as imaging medium. The time lapse images were acquired with an IX-71 inverted microscope (Olympus) equipped with a Polychrome IV monochromator (TILL Photonics) with the appropriate filters, an Andor iXon (Andor) camera, a heated sample environment $\left(+37^{\circ} \mathrm{C}\right)$ and $\mathrm{CO}_{2}$-control. A PLAPON 60xO TIRFM $60 x / 1,45$ (oil) objective (Olympus) was used. Software for image acquisition was TILL Vision version 4 (TILL Photonics).

\section{Nuclear magnetic resonance}

After defrosting $100 \mu \mathrm{l}$ of the purified ${ }^{15} \mathrm{~N}$ labelled ALP (1.6 mM) in buffer solution (20 mM TRIS, $150 \mathrm{mM} \mathrm{NaCl}$, 
$1 \mathrm{mM}$ EDTA and $1 \mathrm{mM}$ DTT, pH 8), a NMR sample of pure ALP was prepared by adding $10 \% \mathrm{D}_{2} \mathrm{O}$ to the defrosted ALP and transferring the sample to a susceptibility matched Shigemi tube (Shigemi Inc., tube matched to water with $8 \mathrm{~mm}$ bottom). Initially, a ${ }^{15} \mathrm{~N}-\mathrm{HSQC}$ spectrum of ALP107-273 was acquired as a reference spectrum. The titration series was initiated by preparing a sample containing $45 \mathrm{nmol}$ ALP, $15 \mathrm{nmol}$ rod domain of $\alpha$-actinin (R1-R4, $277 \mu \mathrm{M}$ and $236 \mu \mathrm{M}$ in $20 \mathrm{mM}$ TRIS and $50 \mathrm{mM} \mathrm{NaCl}, \mathrm{pH} 8), 15 \mu$ buffer solution of R1-R4 and $10 \% \mathrm{D}_{2} \mathrm{O}$ to a susceptibility matched Shigemi tube. A ${ }^{15} \mathrm{~N}$ HSQC spectrum was measured and the titration was continued in a stepwise manner by adding $15 \mathrm{nmol}$ of R1-R4 to the sample and acquiring a new ${ }^{15} \mathrm{~N}-\mathrm{HSQC}$ spectrum at each titration point, until the ratio of 3:8 (ALP:R1-R4) was reached. As a control, titration of ALP was performed with R1-R4 buffer (20 mM TRIS and $50 \mathrm{mM} \mathrm{NaCl}, \mathrm{pH}$ 8). In order to enable direct comparison of the ${ }^{15} \mathrm{~N}$ HSQC spectra at each data point, identical experimental and processing parameters were employed. Measurements were performed with a Bruker Avance DRX $500 \mathrm{MHz}$ spectrometer (Bruker BioSciences, Billerica, Massachusetts, USA) and a $5 \mathrm{~mm}$ triple resonance inverse probehead at room temperature. Measurement of ${ }^{15} \mathrm{~N} /{ }^{13} \mathrm{C}$ enriched ALP was performed with a Varian Unity INOVA $800 \mathrm{MHz}$ spectrometer (Varian, Palo Alto, California).

\section{Surface plasmon resonance}

A Biacore 3000 system (Biacore, Uppsala, Sweden) was used for surface plasmon resonance (SPR) analysis. Ligand immobilization was performed via amine coupling to gold sensor chips (CM5). The running buffer was $20 \mathrm{mM}$ Tris, pH 7.4, $150 \mathrm{mM} \mathrm{NaCl}, 0.005 \%$ surfactant P20 (BR1000-54, Biacore AB, Uppsala, Sweden).

\section{Authors' contributions}

TK planned the study together with JY, made the DNA constructs for protein expression and localization, purified the proteins, performed all of the biochemical experiments and wrote the article. AK participated in DNA cloning and protein expression. NA made the NMR measurements and did the analysis together with PP and SM. $\mathrm{PH}$ performed the time lapse microscopy experiment. $\mathrm{HH}$ made and analyzed the ALP deletion GFP constructs. JY supervised the study, analyzed the data and wrote the article. All authors participated in the writing and have read and approved the final manuscript.

\section{Acknowledgements}

We thank Minna Leuanniemi for expert purification of $\alpha$-actinin fragments and Päivi Pirilä for valuable advice in CD spectroscopy. This work was funded by the Academy of Finland research grants 51863, 20702 I, I052II, and 122170 and by the Finnish Heart Research Foundation.

\section{References}

I. Frank D, Kuhn C, Katus HA, Frey N: The sarcomeric Z-disc: a nodal point in signalling and disease. I Mol Med 2006, 84(6):446-468.
2. Blanchard $A$, Ohanian $\mathrm{V}$, Critchley $\mathrm{D}$ : The structure and function of alpha-actinin. J Muscle Res Cell Motil 1989, I0(4):280-289.

3. Broderick MJ, Winder SJ: Towards a complete atomic structure of spectrin family proteins. J Struct Biol 2002, I37( I-2): |84- I93.

4. McKeown CR, Han HF, Beckerle MC: Molecular characterization of the Caenorhabditis elegans ALP/Enigma gene alp-I. Dev Dyn 2006, 235(2):530-538.

5. Xia H, Winokur ST, Kuo WL, Altherr MR, Bredt DS: Actinin-associated LIM protein: identification of a domain interaction between PDZ and spectrin-like repeat motifs. J Cell Biol I997, I39(2):507-5I5.

6. Faulkner G, Pallavicini A, Formentin E, Comelli A, levolella C, Trevisan S, Bortoletto G, Scannapieco P, Salamon M, Mouly V, et al.: ZASP: a new Z-band alternatively spliced PDZ-motif protein. J Cell Biol 1999, I46(2):465-475.

7. Guy PM, Kenny DA, Gill GN: The PDZ domain of the LIM protein enigma binds to beta-tropomyosin. Mol Biol Cell 1999, I0(6): 1973-1984.

8. Pomies P, Macalma T, Beckerle MC: Purification and characterization of an alpha-actinin-binding PDZ-LIM protein that is Up-regulated during muscle differentiation. J Biol Chem 1999, 274(4I):29242-29250.

9. Zhou Q, Ruiz-Lozano P, Martone ME, Chen J: Cypher, a striated muscle-restricted PDZ and LIM domain-containing protein, binds to alpha-actinin-2 and protein kinase C. J Biol Chem 1999, 274(28): 19807-198|3.

10. Nakagawa N, Hoshijima M, Oyasu M, Saito N, Tanizawa K, Kuroda S: ENH, containing PDZ and LIM domains, heart/skeletal muscle-specific protein, associates with cytoskeletal proteins through the PDZ domain. Biochem Biophys Res Commun 2000, 272(2):505-5I2.

II. Passier R, Richardson JA, Olson EN: Oracle, a novel PDZ-LIM domain protein expressed in heart and skeletal muscle. Mech Dev 2000, 92(2):277-284.

12. Niederlander N, Fayein NA, Auffray C, Pomies P: Characterization of a new human isoform of the enigma homolog family specifically expressed in skeletal muscle. Biochem Biophys Res Commun 2004, 325(4): | $304-|3| \mid$.

13. Wang $\mathrm{H}$, Harrison-Shostak DC, Lemasters JJ, Herman B: Cloning of a rat CDNA encoding a novel LIM domain protein with high homology to rat RIL. Gene 1995, 165(2):267-27I.

14. Kotaka M, Ngai SM, Garcia-Barcelo M, Tsui SK, Fung KP, Lee CY, Waye MM: Characterization of the human 36-kDa carboxyl terminal LIM domain protein (hCLIMI). J Cell Biochem 1999, 72(2):279-285.

15. Kotaka M, Kostin S, Ngai S, Chan K, Lau Y, Lee SM, Li H, Ng EK, Schaper J, Tsui SK, et al.: Interaction of hCLIMI, an enigma family protein, with alpha-actinin 2. J Cell Biochem 2000, 78(4):558-565.

16. Vallenius T, Mäkelä TP: ClikI: a novel kinase targeted to actin stress fibers by the CLP-36 PDZ-LIM protein. J Cell Sci 2002, I I 5(Pt I0):2067-2073.

17. Vallenius T, Scharm B, Vesikansa A, Luukko K, Schafer R, Mäkelä TP: The PDZ-LIM protein RIL modulates actin stress fiber turnover and enhances the association of alpha-actinin with $F$ actin. Exp Cell Res 2004, 293(I): I 17-128.

18. Kiess M, Scharm B, Aguzzi A, Hajnal A, Klemenz R, Schwarte-Waldhoff I, Schafer R: Expression of ril, a novel LIM domain gene, is down-regulated in Hras-transformed cells and restored in phenotypic revertants. Oncogene 1995, I0(I):61-68.

19. Bashirova AA, Markelov ML, Shlykova TV, Levshenkova EV, Alibaeva RA, Frolova El: The human RIL gene: mapping to human chromosome $5 \mathrm{q} 3 \mathrm{I}$. I, genomic organization and alternative transcripts. Gene 1998, 21 0(2):239-245.

20. Torrado M, Senatorov VV, Trivedi R, Fariss RN, Tomarev SI: Pdlim2, a novel PDZ-LIM domain protein, interacts with alphaactinins and filamin A. Invest Ophthalmol Vis Sci 2004, 45(I I):3955-3963.

21. Loughran G, Healy NC, Kiely PA, Huigsloot M, Kedersha NL, O'Connor $\mathrm{R}$ : Mystique is a new insulin-like growth factor-I-regulated PDZ-LIM domain protein that promotes cell attachment and migration and suppresses Anchorage-independent growth. Mol Biol Cell 2005, I6(4): I8I I-1822.

22. Pashmforoush M, Pomies P, Peterson KL, Kubalak S, Ross J Jr, Hefti A, Aebi U, Beckerle MC, Chien KR: Adult mice deficient in actinin-associated LIM-domain protein reveal a developmental pathway for right ventricular cardiomyopathy. Nat Med 200I, 7(5):59I-597. 
23. Zhou Q, Chu PH, Huang C, Cheng CF, Martone ME, Knoll G, Shelton GD, Evans S, Chen J: Ablation of Cypher, a PDZ-LIM domain Zline protein, causes a severe form of congenital myopathy. J Cell Biol 200I, I55(4):605-6I2.

24. Jani K, Schöck F: Zasp is required for the assembly of functional integrin adhesion sites. J Cell Biol 2007, I79(7): I583-1597.

25. Schulz TW, Nakagawa T, Licznerski P, Pawlak V, Kolleker A, Rozov A, Kim J, Dittgen T, Kohr G, Sheng M, et al.: Actin/alpha-actinindependent transport of AMPA receptors in dendritic spines: role of the PDZ-LIM protein RIL. J Neurosci 2004, 24(39):8584-8594.

26. Au Y, Atkinson RA, Guerrini R, Kelly G, Joseph C, Martin SR, Muskett FW, Pallavicini A, Faulkner G, Pastore A: Solution structure of ZASP PDZ domain; implications for sarcomere ultrastructure and enigma family redundancy. Structure (Camb) 2004, I 2(4):6I I-622.

27. Klaavuniemi T, Kelloniemi A, Ylänne J: The ZASP-like motif in actinin-associated LIM protein is required for interaction with the alpha-actinin rod and for targeting to the muscle Zline. I Biol Chem 2004, 279(25):26402-264I0.

28. Bauer K, Kratzer M, Otte M, de Quintana KL, Hagmann J, Arnold GJ, Eckerskorn C, Lottspeich F, Siess W: Human CLP36, a PDZ domain and LIM-domain protein, binds to alpha-actinin-I and associates with actin filaments and stress fibers in activated platelets and endothelial cells. Blood 2000, 96(I3):4236-4245.

29. Klaavuniemi T, Ylänne J: Zasp/Cypher internal ZM-motif containing fragments are sufficient to co-localize with alphaactinin - analysis of patient mutations. Exp Cell Res 2006, 3 I 2(8): | 299-|3|I.

30. Vatta M, Mohapatra B, Jimenez S, Sanchez X, Faulkner G, Perles Z Sinagra G, Lin JH, Vu TM, Zhou Q, et al.: Mutations in Cypherl ZASP in patients with dilated cardiomyopathy and left ventricular non-compaction. I Am Coll Cardiol 2003 42(II):20I4-2027.

31. Selcen D, Engel AG: Mutations in ZASP define a novel form of muscular dystrophy in humans. Ann Neurol 2005, 57(2):269-276.

32. Te Velthuis AJ, Isogai T, Gerrits L, Bagowski CP: Insights into the molecular evolution of the PDZ/LIM family and identification of a novel conserved protein motif. PLOS ONE 2007, 2(2):el89.

33. Prilusky J, Felder CE, Zeev-Ben-Mordehai T, Rydberg EH, Man O, Beckmann JS, Silman I, Sussman JL: FoldIndex(C): a simple tool to predict whether a given protein sequence is intrinsically unfolded. Bioinformatics 2005, 21(16):3435-3438.

34. Schultz J, Milpetz F, Bork P, Ponting CP: SMART, a simplemodular architecture research tool: identification of signaling domains. Proc Natl Acad Sci USA I 998, 95(I I):5857-5864.

35. Linding R, Jensen LJ, Diella F, Bork P, Gibson TJ, Russell RB: Protein disorder prediction: implications for structural proteomics. Structure (Camb) 2003, I I (I I): I453-I459.

36. Bondos SE, Bicknell A: Detection and prevention of protein aggregation before, during, and after purification. Anal Biochem 2003, 316(2):223-23I.

37. Golovanov AP, Hautbergue GM, Wilson SA, Lian LY: A simple method for improving protein solubility and long-term stability. J Am Chem Soc 2004, I 26(29):8933-8939.

38. Alho N, Klaavuniemi T, Ylänne J, Permi P, Mattila S: Backbone NMR assignment of the internal interaction site of ALP. Biomolecular NMR Assignments 2007, I(I):85.

39. Spera $S, B a x A$ : Empirical correlation between protein backbone conformation and Calpha and Cbeta I3-C nuclear magnetic resonance chemical shifts. J Am Chem Soc I991, I I 3:5490-5492.

40. Small JV: Structure-function relationships in smooth muscle: the missing links. BioEssays 1995, I7(9):785-792.

41. Vlahos C], McDowell SA, Clerk A: Kinases as therapeutic targets for heart failure. Nat Rev Drug Discov 2003, 2(2):99-II3.

42. Wilkins BJ, Molkentin JD: Calcium-calcineurin signaling in the regulation of cardiac hypertrophy. Biochem Biophys Res Commun 2004, 322(4): $1178-1191$.

43. Vega RB, Bassel-Duby R, Olson EN: Control of cardiac growth and function by calcineurin signaling. J Biol Chem 2003, 278(39):3698।-36984.

44. Kuroda S, Tokunaga $\mathrm{C}$, Kiyohara $\mathrm{Y}$, Higuchi $\mathrm{O}$, Konishi H, Mizuno K Gill GN, Kikkawa U: Protein-protein interaction of zinc finger
LIM domains with protein kinase C. I Biol Chem 1996, 27 I (49):3 I 029-3I 032.

45. Frey N, Olson EN: Calsarcin-3, a novel skeletal muscle-specific member of the calsarcin family, interacts with multiple Zdisc proteins. J Biol Chem 2002, 277(16): 13998-14004.

46. Djinovic-Carugo K, Young P, Gautel M, Saraste M: Structure of the alpha-actinin rod: molecular basis for cross-linking of actin filaments. Cell 1999, 98(4):537-546.

47. Ylänne J, Scheffzek K, Young P, Saraste M: Crystal Structure of the alpha-Actinin Rod Reveals an Extensive Torsional Twist. Structure 200I, 9(7):597-604.

48. Hotulainen P, Lappalainen P: Stress fibers are generated by two distinct actin assembly mechanisms in motile cells. J Cell Biol 2006, I73(3):383-394.

49. Sambrook J, Russell DW: Molecular Cloning, a laboratory mamual. 3rd edition. New York: Cold Spring Harbor Laboratory Press; 200I.
Publish with Bio Med Central and every scientist can read your work free of charge

"BioMed Central will be the most significant development for disseminating the results of biomedical research in our lifetime. "

Sir Paul Nurse, Cancer Research UK

Your research papers will be:

- available free of charge to the entire biomedical community

- peer reviewed and published immediately upon acceptance

- cited in PubMed and archived on PubMed Central

- yours - you keep the copyright

Submit your manuscript here:

http://www.biomedcentral.com/info/publishing_adv.asp
BioMedcentral 